\title{
Technical note: 3-hourly temporal downscaling of monthly global terrestrial biosphere model net ecosystem exchange
}

\author{
Joshua B. Fisher ${ }^{1}$, Munish Sikka ${ }^{1}$, Deborah N. Huntzinger ${ }^{2}$, Christopher Schwalm ${ }^{3}$, and Junjie Liu ${ }^{1}$ \\ ${ }^{1}$ Jet Propulsion Laboratory, California Institute of Technology, 4800 Oak Grove Drive, Pasadena, CA 91109, USA \\ ${ }^{2}$ School of Earth Sciences and Environmental Sustainability, Northern Arizona University, 527 S. Beaver St., Flagstaff, AZ \\ 86011-5694, USA \\ ${ }^{3}$ Woods Hole Research Center, Falmouth, MA 02540, USA
}

Correspondence to: Joshua B. Fisher (joshbfisher@gmail.com)

Received: 25 February 2016 - Published in Biogeosciences Discuss.: 14 March 2016

Revised: 13 June 2016 - Accepted: 22 June 2016 - Published: 29 July 2016

\begin{abstract}
The land surface provides a boundary condition to atmospheric forward and flux inversion models. These models require prior estimates of $\mathrm{CO}_{2}$ fluxes at relatively high temporal resolutions (e.g., 3-hourly) because of the high frequency of atmospheric mixing and wind heterogeneity. However, land surface model $\mathrm{CO}_{2}$ fluxes are often provided at monthly time steps, typically because the land surface modeling community focuses more on time steps associated with plant phenology (e.g., seasonal) than on sub-daily phenomena. Here, we describe a new dataset created from 15 global land surface models and 4 ensemble products in the Multi-scale Synthesis and Terrestrial Model Intercomparison Project (MsTMIP), temporally downscaled from monthly to 3-hourly output. We provide 3-hourly output for each individual model over 7 years (2004-2010), as well as an ensemble mean, a weighted ensemble mean, and the multi-model standard deviation. Output is provided in three different spatial resolutions for user preferences: $0.5^{\circ} \times 0.5^{\circ}, 2.0^{\circ} \times 2.5^{\circ}$, and $4.0^{\circ} \times 5.0^{\circ}$ (latitude $\times$ longitude). These data are publicly available from doi:10.3334/ORNLDAAC/1315.
\end{abstract}

\section{Approach}

This technical note describes the methodological approach employed with temporally downscaling monthly terrestrial biosphere model (TBM) net ecosystem exchange (NEE) (i.e., net $\mathrm{CO}_{2}$ flux between the land and atmosphere) output to 3hourly time steps (Fisher et al., 2014). These data were created initially for NASA's Carbon Monitoring System (CMS) and are useful to the broader land surface and atmospheric scientific community (Fisher et al., 2011, 2012). The general downscaling approach follows Olsen and Randerson (2004) with modifications. The logic takes the components of NEE, i.e., gross primary production (GPP) and ecosystem respiration $(\mathrm{Re})$, and links them with incident shortwave solar radiation $(I)$ and near-surface $(2 \mathrm{~m})$ air temperature $\left(T_{\mathrm{a}}\right)$, respectively. $I$ and $T_{\text {a }}$ are provided at 6-hourly time steps from CRU-NCEP (Wei et al., 2014a, b), which we interpolated to 3-hourly time steps following cosines of solar zenith angle for $I$ and linear interpolation for $T_{\mathrm{a}}$. Hence, GPP and Re are temporally downscaled to 3-hourly and re-combined to form NEE at 3-hourly time steps.

The 6-hourly to two 3-hourly time steps from the solar zenith angle cosine interpolation follows this equation:

$I_{t 1}=\frac{I_{t} \times \cos z_{t 1}}{\left(\frac{\cos z_{t 1}+\cos z_{t-t 1}}{2}\right)}, I_{t-t 1}=\frac{I_{t} \times \cos z_{t-t 1}}{\left(\frac{\cos z_{t 1}+\cos z_{t-t 1}}{2}\right)}$,

where $z$ is solar zenith angle and $I_{t}$ is in units of $\mathrm{W} \mathrm{m}^{-2}$. As an example, if the $0-6 \mathrm{~h} I_{t}$ were $100 \mathrm{~W} \mathrm{~m}^{-2}$, the $0-3 \mathrm{~h} z_{t 1}$ were 0 (i.e., $\cos \left(z_{t 1}\right)=1$ ), and the $4-6 \mathrm{~h} z_{t-t 1}$ were 60 (i.e., $\left.\cos \left(z_{t-t 1}\right)=0.5\right)$, then the $0-3 \mathrm{~h} I_{t 1}$ would be $133.3 \mathrm{~W} \mathrm{~m}^{-2}$, and the $4-6 \mathrm{~h} I_{t-t 1}$ would be $66.7 \mathrm{~W} \mathrm{~m}^{-2}$.

To scale GPP and Re to 3-hourly time steps, we followed Olsen and Randerson (2004) with modifications starting first with the calculation of scale factors based on $I$ and $T_{\mathrm{a}}$ :

$Q 10_{3 \mathrm{~h}}=1.5^{\frac{T_{\mathrm{a}, 3 \mathrm{~h}}-30}{10}}$, 


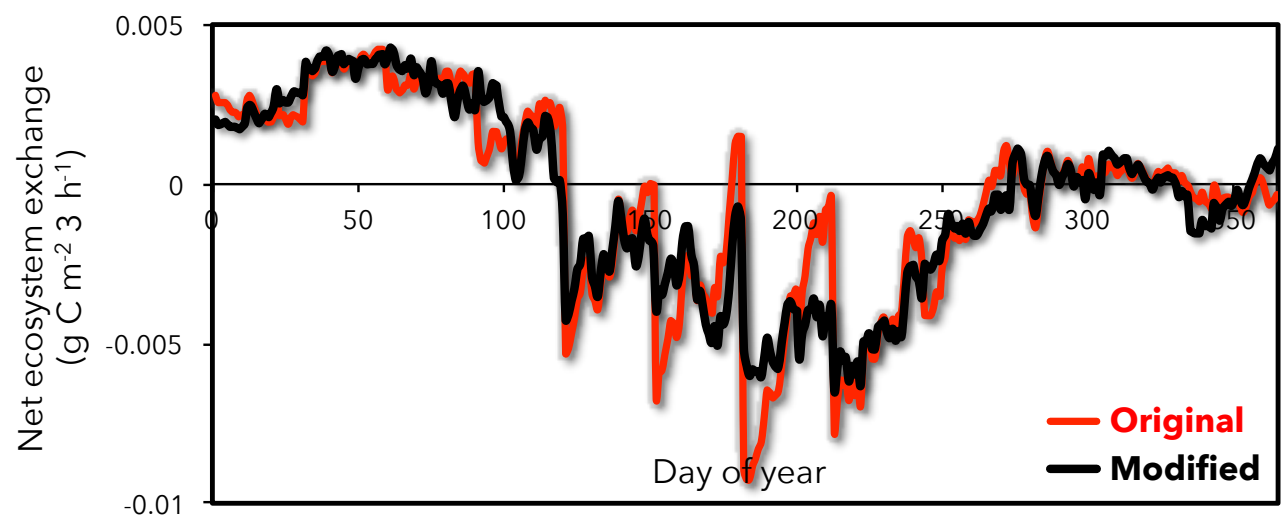

Figure 1. The original downscaling approach of Olsen and Randerson (2004) used monthly fixed values, which led to a "stair-stepping" behavior between months (red). This was eliminated by using a 30-day moving window and interpolating monthly input values to 3-hourly time steps (black). Example shown for Lund-Potsdam-Jena (LPJ) model global mean year 2005.

$T_{\text {scale }}=Q 10_{3 \mathrm{~h}} / \sum_{30 \text { day }} Q 10_{3 \mathrm{~h}}$

$I_{\text {scale }}=I_{3 \mathrm{~h}} / \sum_{30 \text { day }} I_{3 \mathrm{~h}}$,

where $Q 10$ is the temperature dependency of Re, and $T_{\mathrm{a}}$ is in degrees Celsius (converted from kelvin, as provided by CRU-NCEP). Note that Olsen and Randerson (2004) originally used time integral periods of calendar months, but we observed that this caused unrealistic distinct shifts between months. Instead, we modified the integral period to a 30-day moving window (Fig. 1). For the first 15 days of January of the record and the last 15 days of December of the record, we used the last 15 days of December and the first 15 days of January, respectively, within the first (2004) and last (2010) years to complete the 30-day window.

The 3-hourly resolution scale factors are then multiplied by GPP and Re for each 3-hourly time step each month:

$\operatorname{Re}_{3 \mathrm{~h}}=T_{\text {scale }} \times \operatorname{Re}_{\text {month }}$,

$\mathrm{GPP}_{3 \mathrm{~h}}=I_{\text {scale }} \times \mathrm{GPP}_{\text {month }}$.

We modified $\mathrm{Re}_{\text {month }}$ and $\mathrm{GPP}_{\text {month }}$ from Olsen and Randerson (2004) to be given at a 3-hourly time step, linearly interpolated to 3-hourly time steps based on the present, previous, and subsequent month, maintaining the original units $\left(\mathrm{g} \mathrm{C} \mathrm{m}^{-2}\right.$ months $\left.{ }^{-1}\right) . \mathrm{Re}_{3 \mathrm{~h}}$ and $\mathrm{GPP}_{3 \mathrm{~h}}$ are in units of $\mathrm{g} \mathrm{C} \mathrm{m}^{-2} 3 \mathrm{~h}^{-1}$. This modification avoided using the same monthly value for the multiplier for all 3-hourly time steps per month as per Olsen and Randerson (2004) and instead provided a smooth transition from one month to the next. The result of this modification was to eliminate a "ramping" effect whereby values would, for example, increase steadily within a month, then suddenly shift to a new starting point at the beginning of the next month (Fig. 1). Note that the original nomenclature of Olsen and Randerson (2004) used $\left[\left(2 \times \mathrm{NPP}_{\text {month }}\right)-\mathrm{NEP}_{\text {month }}\right]$ in place of $\mathrm{Re}_{\text {month }}$ and $\left(2 \times \mathrm{NPP}_{\text {month }}\right)$ in place of $\mathrm{GPP}_{\text {month }}$, where NPP is net primary production (GPP minus autotrophic respiration) and NEP is net ecosystem production (approximately equivalent to the inverse sign of NEE, with caveats; Hayes and Turner, 2012). The assumption here, therefore, is that GPP $=$ $2 \times \mathrm{NPP}$ and $\mathrm{Re}=(2 \times \mathrm{NPP})-\mathrm{NEP}$. The Re assumption misses $\mathrm{CO}_{2}$ emissions other than respiration, e.g., fire, which we correct for at a later step.

The initial NEE calculation simply subtracts GPP from Re:

$\mathrm{NEE}_{3 \mathrm{~h}}=\mathrm{Re}_{3 \mathrm{~h}}-\mathrm{GPP}_{3 \mathrm{~h}}$,

where $\mathrm{NEE}_{3 \mathrm{~h}}$ is calculated in units of $\mathrm{g} \mathrm{C} \mathrm{m}^{-2} 3 \mathrm{~h}^{-1}$. However, we applied an additional unit conversion for the publicly available data to $\mathrm{kg} \mathrm{C} \mathrm{km}^{-2} \mathrm{~s}^{-1}$, as these units are more readily ingestible by atmospheric inversion models (Deng et al., 2014).

Because the downscaling approach uses Re (e.g., autotrophic plus heterotrophic respiration) as the primary $\mathrm{CO}_{2}$ efflux term, other ecosystem $\mathrm{CO}_{2}$ loss components, such as fire and other disturbances (Hayes and Turner, 2012), are excluded in the downscale. Hence, the sum of the downscaled 3-hourly NEE fluxes in a given month did not necessarily equal the original monthly NEE flux. So, we included a per-pixel correction whereby we (i) calculated the difference between the sum of the downscaled 3-hourly NEE in a given month and the original monthly NEE, (ii) divided that difference by the total 3-hourly time steps in the month, and (iii) added that difference to each 3-hourly NEE flux. In so doing, the sum of the downscaled 3-hourly NEE fluxes subsequently summed exactly to the original monthly NEE. Nonetheless, this assumption smooths what could otherwise be punctuated fire or disturbance effluxes, so caution should be given when assessing these effluxes at 3-hourly time steps (e.g., relative to observations). 

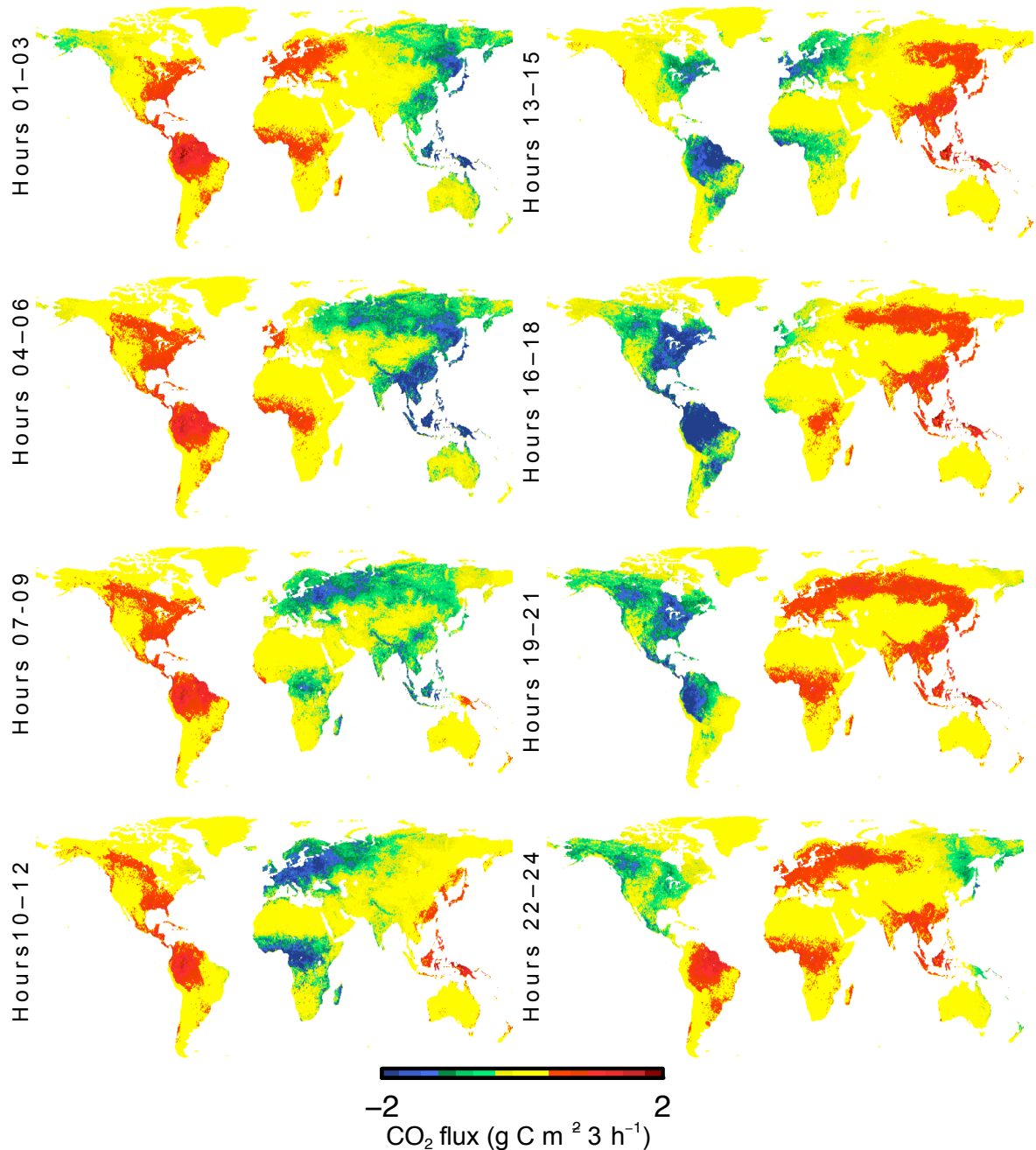

Figure 2. Vegetation productivity (e.g., blues/greens) follows the course of the Sun for a single day of net ecosystem exchange (NEE or net $\mathrm{CO}_{2}$ flux; $\mathrm{g} \mathrm{C} \mathrm{m}^{-2} 3 \mathrm{~h}^{-1}$ ) for each 3-hourly period. Shown here, for example, is 1 July 2007 for the weighted ensemble mean product.

All input data were given in a spatial resolution of $0.5^{\circ} \times 0.5^{\circ}$ (latitude $\times$ longitude); hence, we provide the 3 hourly NEE output at $0.5^{\circ} \times 0.5^{\circ}$ (Fig. 2). We also provide two additional sets of spatially upscaled NEE output at $2.0^{\circ} \times 2.5^{\circ}$ and $4.0^{\circ} \times 5.0^{\circ}$. These resolutions are used by the atmospheric modeling community, i.e., the GEOSChem atmospheric $\mathrm{CO}_{2}$ transport model in the NASA CMS (Liu et al., 2014). To generate the coarser-resolution data, we (i) multiplied each pixel value by the land area of that pixel; (ii) summed the flux from all pixels that represent one pixel at coarser resolution (e.g., $8 \times 10$ pixels from $0.5^{\circ} \times 0.5^{\circ}$ comprise 1 pixel in $4.0^{\circ} \times 5.0^{\circ}$ ); (iii) calculated the total area covered by the pixels summed in step (ii); and (iv) divided the value in step (ii) by the value in step (iii). The regridding preserved the total sum flux of the finer grid cells as well as the total global flux. We provide a file containing the land area contained in each latitudinal band for each of the three resolutions (folder name: "latitude_area"). We pro- vide two versions of the $2.0^{\circ} \times 2.5^{\circ}$ and $4.0^{\circ} \times 5.0^{\circ}$ resolution products - one version with consistent global resolution, and another that conforms to the GEOS-Chem setup whereby the northern- and southern-most latitudinal bands for the $2.0^{\circ} \times 2.5^{\circ}$ resolution are $1.0^{\circ} \times 2.5^{\circ}$, and for the $4.0^{\circ} \times 5.0^{\circ}$ resolution they are $2.0^{\circ} \times 5.0^{\circ}$. The orientation of the global grid in the NetCDF files is transposed (i.e., $90^{\circ} \mathrm{S} \times 180^{\circ} \mathrm{W}$ at top left). The time vector represents the midpoint of each 3-hourly period.

Processing time in $R$, unparallelized, on a standard PC for a single year for the forcing data was as follows:

- interpolation of 6-hourly $I$ and $T_{\mathrm{a}}$ to 3-hourly time step: $1 \mathrm{~h}$ per variable;

- 30-day moving window for $I: 48 \mathrm{~h}$;

- 30-day moving window for $T_{\mathrm{a}}: 68 \mathrm{~h}$; 


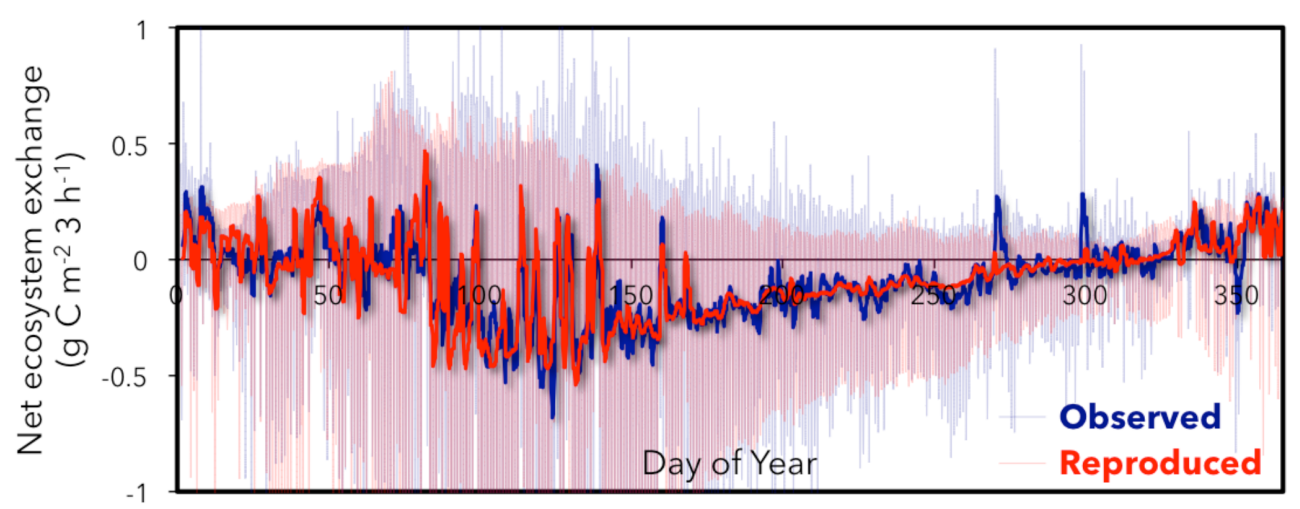

Figure 3. The observed net ecosystem exchange (NEE) (blue) and reproduced NEE (red) shown at the 3-hourly time step with daily moving window overlaid for a single year from the Tonzi Ranch AmeriFlux/FLUXNET site (Baldocchi and Ma, 2013).

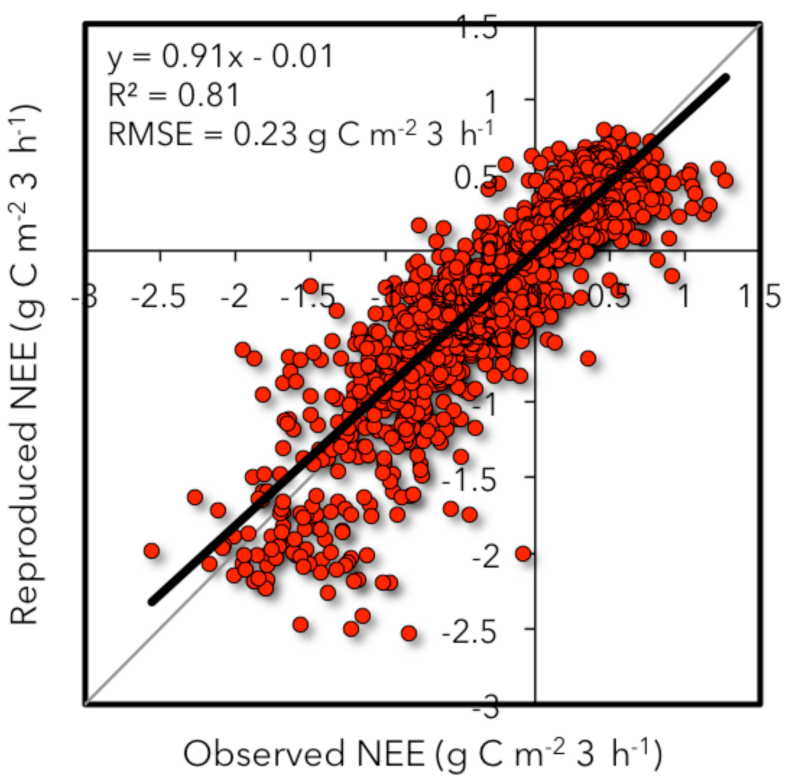

Figure 4. Observed versus reproduced net ecosystem exchange (NEE) at the 3-hourly time step for a single year at the Tonzi Ranch AmeriFlux/FLUXNET site (Baldocchi and Ma, 2013).

- total time to process forcing data for 7 years: $7 \times(1 \times 2+48+68)=826 \mathrm{~h}$.

Processing time for the application of the modified Olsen and Randerson (2004) downscaling approach for a single model for a single year was as follows:

- monthly interpolation to 3-hourly time steps for GPP: $1 \mathrm{~h}$;

- monthly interpolation to 3-hourly time steps for Re: $1 \mathrm{~h}$;

- GPP and Re downscaling: $2 \mathrm{~h}$;

- monthly NEE closure correction: $1 \mathrm{~h}$;
Table 1. Global terrestrial biosphere models from the Multi-scale Synthesis and Terrestrial Model Intercomparison Project (MsTMIP) downscaled in this activity.

\begin{tabular}{ll}
\hline Model & Reference \\
\hline BIOME_BGC & Thornton et al. (2002) \\
CLM & Mao et al. (2012) \\
CLM4VIC & Lei et al. (2014) \\
CLASS_CTEM & Huang et al. (2011) \\
DLEM & Tian et al. (2012) \\
GTEC & Ricciuto et al. (2011) \\
ISAM & Jain and Yang (2005) \\
LPJ-ws1 & Sitch et al. (2003) \\
ORCHIDEE & Krinner et al. (2005) \\
SIB3 & Baker et al. (2008) \\
SIBCASA & Schaefer et al. (2008) \\
TEM6 & Hayes et al. (2011) \\
TRIPLEX-GHG & Peng et al. (2002) \\
VEGAS2.1 & Zeng et al. (2005) \\
VISIT & Ito (2010) \\
\hline
\end{tabular}

- NetCDF generation with additional spatial resolutions: $2 \mathrm{~h}$;

- total time to process all 19 products for 7 years: $7 \times 19 \times(1+1+2+1+2)=931 \mathrm{~h}$.

The total storage size of the final NetCDF data products for all 19 products ( 15 models +4 ensemble products) for all 7 years is $374 \mathrm{~GB}$ at $0.5^{\circ} \times 0.5^{\circ}, 38 \mathrm{~GB}$ at $2.0^{\circ} \times 2.5^{\circ}$, and $10 \mathrm{~GB}$ at $4.0^{\circ} \times 5.0^{\circ}$.

We provide the data in NetCDF with a separate file for each day per product at doi:10.3334/ORNLDAAC/1315 (Fisher et al., 2016). Each file contains the global gridded data with the eight 3-hourly intervals in the day. Open-water pixels are set to 0 , as this was desired by the atmospheric modeling community. However, we realize that NEE values can conceivably be 0 (though unlikely as our precision is to 16 decimal places); nonetheless, there are some pixels over 
land that are calculated as 0 , but this is due to missing forcing data (e.g., $I$ at the high latitudes during winter). Our code is set up such that we can easily provide a different file output structure and missing value mask by request (contact the corresponding author: jbfisher@jpl.nasa.gov).

Model output (GPP, Re, and NEE) was from the Multiscale Synthesis and Terrestrial Model Intercomparison Project (MsTMIP) (Huntzinger et al., 2013, 2016), version 1. Fifteen models were included: (1) BIOME_BGC, (2) CLM, (3) CLM4VIC, (4) CLASS_CTEM, (5) DLEM, (6) GTEC, (7) ISAM, (8) LPJ-wsl, (9) ORCHIDEE, (10) SIB3, (11) SIBCASA, (12) TEM6, (13) TRIPLEXGHG, (14) VEGAS2.1, and (15) VISIT (Table 1). All models were driven by CRU-NCEP meteorological forcing data, hence our use of the same data source for the downscaling approach applied here. We note that there are other meteorological forcing datasets also available at 3-hourly time steps for those interested in applying our downscaling approach with different data (Sheffield et al., 2006; Weedon et al., 2011, 2014). Although some models are capable of output at sub-monthly time steps, the standard MsTMIP output is at the monthly time step. Additionally, four ensemble products were included: (1) unweighted (naïve) ensemble mean, (2) unweighted (naïve) ensemble standard deviation, (3) weighted (optimal) ensemble mean, and (4) weighted (optimal) ensemble standard deviation. Weights for model ensemble integration were derived based on model skill in reproducing GPP and biomass (Schwalm et al., 2015). Model output was obtained from ftp://nacp.ornl.gov/synthesis/2009/ reutlingen/CMS/20141006/.

To test and confirm that our downscaling approach was applied correctly, we tested our method on a set of groundtruth data of measured NEE (and forcing variables) from the FLUXNET database (Baldocchi et al., 2001). We show, for example, a single year for a single site (3-hourly in background with daily-moving window overlaid) (Fig. 3) and the scatterplot of calculated versus observed NEE values at the 3-hourly time step for that site and year (Fig. 4). A full uncertainty analysis of the approach is beyond the scope of this technical note, intended to describe the methodological detail of the downscaling.

\section{Data availability}

The data are available for download in NetCDF at doi:10.3334/ORNLDAAC/1315.

Author contributions. Joshua B. Fisher, Deborah N. Huntzinger, and Christopher Schwalm formulated the idea; Joshua B. Fisher and Munish Sikka designed the research; Munish Sikka performed the research; Deborah N. Huntzinger and Christopher Schwalm provided data; all authors contributed to the writing of the paper.
Acknowledgements. Funding for this work was provided by NASA's Carbon Monitoring System (CMS) and NASA's Carbon Cycle Science (CARBON) programs. We thank the MsTMIP modeling teams for providing the model output. Access and information about MsTMIP model output can be found at http://nacp.ornl.gov/mstmipdata/, along with model and model team participant information. Funding for the MsTMIP activity was provided through NASA ROSES grant no. NNX10AGO01A. Data management support for preparing, documenting, and distributing MsTMIP model driver and output data was performed by the Modeling and Synthesis Thematic Data Center at Oak Ridge National Laboratory with funding through NASA ROSES grant no. NNH10AN681. We thank Dennis Baldocchi and Siyan Ma for providing the Tonzi Ranch AmeriFlux/FLUXNET data; funding for AmeriFlux data resources and core site data was provided by the U.S. Department of Energy's Office of Science. Two reviewers provided useful suggestions on how to improve the paper. The research was carried out at the Jet Propulsion Laboratory, California Institute of Technology, under a contract with the National Aeronautics and Space Administration. Government sponsorship acknowledged. Copyright 2016. All rights reserved.

The authors declare no conflict of interest.

Edited by: P. Stoy

Reviewed by: Z. Zhang and one anonymous referee

\section{References}

Baker, I. T., Prihodko, L., Denning, A. S., Goulden, M., Miller, S., and da Rocha, H. R.: Seasonal drought stress in the Amazon: Reconciling models and observations, J. Geophys. Res., 113, G00B01, doi:10.1029/2007jg000644, 2008.

Baldocchi, D. and Ma, S.: How will land use affect air temperature in the surface boundary layer? Lessons learned from a comparative study on the energy balance of an oak savanna and annual grassland in California, USA, Tellus B, 65, 1-19, doi:10.3402/tellusb.v65i0.19994, 2013.

Baldocchi, D., Falge, E., Gu, L. H., Olson, R. J., Hollinger, D., Running, S. W., Anthoni, P. M., Bernhofer, C., Davis, K., Evans, R., Fuentes, J., Goldstein, A., Katul, G., Law, B. E., Lee, X. H., Malhi, Y., Meyers, T., Munger, W., Oechel, W., U, K. T. P., Pilegaard, K., Schmid, H. P., Valentini, R., Verma, S., Vesala, T., Wilson, K., and Wofsy, S. C.: FLUXNET: A new tool to study the temporal and spatial variability of ecosystem-scale carbon dioxide, water vapor, and energy flux densities, B. Am. Meteorol. Soc., 82, 2415-2434, 2001.

Deng, F., Jones, D. B. A., Henze, D. K., Bousserez, N., Bowman, K. W., Fisher, J. B., Nassar, R., O’Dell, C., Wunch, D., Wennberg, P. O., Kort, E. A., Wofsy, S. C., Blumenstock, T., Deutscher, N. M., Griffith, D. W. T., Hase, F., Heikkinen, P., Sherlock, V., Strong, K., Sussmann, R., and Warneke, T.: Inferring regional sources and sinks of atmospheric $\mathrm{CO}_{2}$ from GOSAT $\mathrm{XCO}_{2}$ data, Atmos. Chem. Phys., 14, 3703-3727, doi:10.5194/acp-14-37032014, 2014.

Fisher, J. B., Huntzinger, D. N., Schwalm, C. R., and Sitch, S.: Modeling the terrestrial biosphere, Annu. Rev. Env. Resour., 39, 91123, 2014. 
Fisher, J. B., Polhamus, A., Bowman, K. W., Liu, J., Lee, M., Jung, M., Reichstein, M., Collatz, G. J., and Potter, C.: Evaluation of NASA's Carbon Monitoring System Flux Pilot: terrestrial $\mathrm{CO}_{2}$ fluxes, San Francisco, CA2011, 2011.

Fisher, J. B., Sikka, M., Bowman, K. W., Liu, J., Lee, M., Collatz, G. J., Pawson, S., and Gunson, M.: CMS Flux Team, TRENDY Modelers, and NACP Regional Synthesis Modelers: The NASA Carbon Monitoring System (CMS) Flux Pilot Project as a means to evaluate global land surface models, American Geophysical Union Fall Meeting, San Francisco, 2012.

Fisher, J. B., Sikka, M., Huntzinger, D. N., Schwalm, C. R., Liu, J., Wei, Y., Cook, R. B., Michalak, A. M., Schaefer, K., Jacobson, A. R., Arain, M. A., Ciais, P., El-Masri, B., Hayes, D. J., Huang, M., Huang, S., Ito, A., Jain, A. K., Lei, H., Lu, C., Maignan, F., Mao, J., Parazoo, N., Peng, C., Peng, S., Poulter, B., Ricciuto, D. M., Tian, H., Shi, X., Wang, W., Zeng, N., Zhao, F., and Zhu, Q.: CMS: Modeled Net Ecosystem Exchange at 3-hourly Time Steps, 2004-2010, doi:10.3334/ORNLDAAC/1315, 2016b.

Hayes, D. and Turner, D.: The need for "apples - to - apples" comparisons of carbon dioxide source and sink estimates, Eos, Transactions American Geophysical Union, 93, 404-405, 2012.

Hayes, D. J., McGuire, A. D., Kicklighter, D. W., Gurney, K. R., Burnside, T. J., and Melillo, J. M.: Is the northern high-latitude land-based $\mathrm{CO}_{2}$ sink weakening?, Global Biogeochem. Cy., 25, GB3018, doi:10.1029/2010GB003813, 2011.

Huang, S., Arain, M. A., Arora, V. K., Yuan, F., Brodeur, J., and Peichl, M.: Analysis of nitrogen controls on carbon and water exchanges in a conifer forest using the CLASS-CTEM N+ model, Ecol. Model., 222, 3743-3760, 2011.

Huntzinger, D. N., Schwalm, C., Michalak, A. M., Schaefer, K., King, A. W., Wei, Y., Jacobson, A., Liu, S., Cook, R. B., Post, W. M., Berthier, G., Hayes, D., Huang, M., Ito, A., Lei, H., Lu, C., Mao, J., Peng, C. H., Peng, S., Poulter, B., Riccuito, D., Shi, X., Tian, H., Wang, W., Zeng, N., Zhao, F., and Zhu, Q.: The North American Carbon Program Multi-Scale Synthesis and Terrestrial Model Intercomparison Project - Part 1: Overview and experimental design, Geosci. Model Dev., 6, 2121-2133, doi:10.5194/gmd-6-2121-2013, 2013.

Huntzinger, D. N., Schwalm, C. R., Wei, Y., Cook, R. B., Michalak, A. M., Schaefer, K., Jacobson, A. R., Arain, M. A., Ciais, P., Fisher, J. B., Hayes, D. J., Huang, M., Huang, S., Ito, A., Jain, A. K., Lei, H., Lu, C., Maignan, F., Mao, J., Parazoo, N., Peng, C., Peng, S., Poulter, B., Ricciuto, D. M., Tian, H., Shi, X., Wang, W., Zeng, N., Zhao, F., and Zhu, Q.: NACP MsTMIP: Global 0.5deg Terrestrial Biosphere Model Outputs (version 1) in Standard Format, ORNL DAAC, Oak Ridge, Tennessee, USA, 2016.

Ito, A.: Changing ecophysiological processes and carbon budget in East Asian ecosystems under near-future changes in climate: implications for long-term monitoring from a process-based model, J. Plant Res., 123, 577-588, 2010.

Jain, A. K. and Yang, X.: Modeling the effects of two different land cover change data sets on the carbon stocks of plants and soils in concert with $\mathrm{CO}_{2}$ and climate change, Global Biogeochem. Cy., 19, GB2015, doi:10.1029/2004gb002349, 2005.

Krinner, G., Viovy, N., de Noblet-Ducoudré, N., Ogé, J., Polcher, J., Friedlingstein, P., Ciais, P., Sitch, S., and Prentice, I. C.: A dynamic global vegetation model for studies of the coupled atmosphere-biosphere system, Global Biogeochem. Cy., 19, GB1015, doi:10.1029/2003gb002199, 2005.
Lei, H., Huang, M., Leung, L. R., Yang, D., Shi, X., Mao, J., Hayes, D. J., Schwalm, C. R., Wei, Y., and Liu, S.: Sensitivity of global terrestrial gross primary production to hydrologic states simulated by the Community Land Model using two runoff parameterizations, Journal of Advances in Modeling Earth Systems, 6, 658-679, 2014.

Liu, J., Bowman, K. W., Lee, M., Henze, D. K., Bousserez, N., Brix, H., Collatz, G. J., Menemenlis, D., Ott, L., and Pawson, S.: Carbon monitoring system flux estimation and attribution: impact of ACOS-GOSAT $\mathrm{XCO}_{2}$ sampling on the inference of terrestrial biospheric sources and sinks, Tellus B, 66, 22486, doi:10.3402/tellusb.v66.22486, 2014.

Mao, J., Thornton, P. E., Shi, X., Zhao, M., and Post, W. M.: Remote Sensing Evaluation of CLM4 GPP for the Period 2000-09*, J. Climate, 25, 5327-5342, 2012.

Olsen, S. C. and Randerson, J. T.: Differences between surface and column atmospheric $\mathrm{CO}_{2}$ and implications for carbon cycle research, J. Geophys. Res.-Atmos., 109, doi:10.1029/2003JD003968, 2004.

Peng, C., Liu, J., Dang, Q., Apps, M. J., and Jiang, H.: TRIPLEX: a generic hybrid model for predicting forest growth and carbon and nitrogen dynamics, Ecol. Model., 153, 109-130, 2002.

Ricciuto, D. M., King, A. W., Dragoni, D., and Post, W. M.: Parameter and prediction uncertainty in an optimized terrestrial carbon cycle model: Effects of constraining variables and data record length, J. Geophys. Res.-Biogeo., 116, doi:10.1029/2010JG001400, 2011.

Schaefer, K., Collatz, G. J., Tans, P., Denning, A. S., Baker, I., Berry, J., Prihodko, L., Suits, N., and Philpott, A.: Combined Simple Biosphere/Carnegie-Ames-Stanford Approach terrestrial carbon cycle model, J. Geophys. Res., 113, G03034, doi:10.1029/2007jg000603, 2008.

Schwalm, C. R., Huntzinger, D. N., Fisher, J. B., Michalak, A. M., Bowman, K., Ciais, P., Cook, R., El-Masri, B., Hayes, D., and Huang, M.: Toward "optimal" integration of terrestrial biosphere models, Geophys. Res. Lett., 42, 4418-4428, 2015.

Sheffield, J., Goteti, G., and Wood, E. F.: Development of a 50-year high-resolution global dataset of meteorological forcings for land surface modeling, J. Climate, 19, 3088-3111, 2006.

Sitch, S., Smith, B., Prentice, C. I., Arneth, A., Bondeau, A., Cramer, W., Kaplan, J. O., Lucht, W., Sykes, M. T., Thonicke, K., and Venevsky, S.: Evaluation of ecosystem dynamics, plant geography and terrestrial carbon cycling in the LPJ dynamic global vegetation model, Glob. Change Biol., 9, 161-185, 2003.

Thornton, P. E., Law, B. E., Gholz, H. L., Clark, K. L., Falge, E., Ellsworth, D. S., Goldstein, A. H., Monson, R. K., Hollinger, D., Paw U, J. C., and Sparks, J. P.: Modeling and measuring the effects of disturbance history and climate on carbon and water budgets in evergreen needleleaf forests, Agr. Forest Meteorol., 113, 185-222, 2002.

Tian, H., Chen, G., Zhang, C., Liu, M., Sun, G., Chappelka, A., Ren, W., Xu, X., Lu, C., and Pan, S.: Century-scale responses of ecosystem carbon storage and flux to multiple environmental changes in the southern United States, Ecosystems, 15, 674-694, 2012.

Weedon, G., Gomes, S., Viterbo, P., Shuttleworth, W., Blyth, E., Österle, H., Adam, J., Bellouin, N., Boucher, O., and Best, M.: Creation of the WATCH forcing data and its use to assess global 
and regional reference crop evaporation over land during the twentieth century, J. Hydrometeorol., 12, 823-848, 2011.

Weedon, G. P., Balsamo, G., Bellouin, N., Gomes, S., Best, M. J., and Viterbo, P.: The WFDEI meteorological forcing data set: WATCH Forcing Data methodology applied to ERA - Interim reanalysis data, Water Resour. Res., 50, 7505-7514, 2014.

Wei, Y., Liu, S., Huntzinger, D., Michalak, A., Viovy, N., Post, W., Schwalm, C., Schaefer, K., Jacobson, A., and Lu, C.: NACP MsTMIP: Global and North American Driver Data for MultiModel Intercomparison, Data set, available at: http://daac.ornl. gov/ (last access: July 2015), Oak Ridge National Laboratory Distributed Active Archive Center, Oak Ridge, Tennessee, USA, 2014a.
Wei, Y., Liu, S., Huntzinger, D. N., Michalak, A. M., Viovy, N., Post, W. M., Schwalm, C. R., Schaefer, K., Jacobson, A. R., Lu, C., Tian, H., Ricciuto, D. M., Cook, R. B., Mao, J., and Shi, X.: The North American Carbon Program Multi-scale Synthesis and Terrestrial Model Intercomparison Project - Part 2: Environmental driver data, Geosci. Model Dev., 7, 2875-2893, doi:10.5194/gmd-7-2875-2014, 2014b.

Zeng, N., Qian, H., Roedenbeck, C., and Heimann, M.: Impact of 1998-2002 midlatitude drought and warming on terrestrial ecosystem and the global carbon cycle, Geophys. Res. Lett., 32, L22709, doi:10.1029/2005g1024607, 2005. 